\title{
Wu Faxian, Suiyue jiannan. Huiyilu (The Hardships of the Times. Memoirs)
}

Ben Xu

\section{(2) OpenEdition \\ 12 Journals}

\section{Electronic version}

URL: http://journals.openedition.org/chinaperspectives/3903

DOI: 10.4000/chinaperspectives.3903

ISSN: 1996-4617

\section{Publisher}

Centre d'étude français sur la Chine contemporaine

\section{Printed version}

Date of publication: 4 April 2008

Number of pages: 108-109

ISSN: 2070-3449

\section{Electronic reference}

Ben Xu, « Wu Faxian, Suiyue jiannan. Huiyilu (The Hardships of the Times. Memoirs) », China Perspectives [Online], 2008/2 | 2008, Online since 01 April 2008, connection on 21 September 2020 URL : http://journals.openedition.org/chinaperspectives/3903 ; DOI : https://doi.org/10.4000/ chinaperspectives.3903

\section{This text was automatically generated on 21 September 2020}

(c) All rights reserved 


\title{
Wu Faxian, Suiyue jiannan. Huiyilu (The Hardships of the Times. Memoirs)
}

\author{
Ben Xu
}

1 The closer we draw to the Mao regime, the clearer it becomes that Mao is the defining figure of China, and that the most defining period of his tyrannical rule was the Cultural Revolution. It is hardly surprising that the end of the Cultural Revolution brought forth a vast outpouring of memoirs. The victims often clung to hope with a vow to "tell the world what went on there." But while China seems to be well into the post-Mao era, many recollections of Mao's regime can still not be published in mainland China, including the memoirs of General Wu Faxian, former Commander-inChief of China's Air Force.

General Wu's massive two-volume memoir has become a bestseller in Hong Kong and is much sought-after in mainland China. Remembering the Mao regime with a view to revealing its cruel and ruthless political infighting is currently taboo in China, and the government is doing all in its power to ensure that certain parts of Communist history be forgotten or at least be talked about with proper decorum.

3 The first volume of General Wu's memoirs recounts the author's glorious past and his rise in the army, moving closer and closer to the whirlpool of "central power." Coming from a poor peasant family and with almost no education, Wu joined the Red Army when he was 15 and then rose steadily in the army echelon. He was indeed a lucky general, never wounded once in battle; the only "wound" he ever received was selfinflicted during a hunting trip. The most revealing parts of Wu's memoir are in the second volume, without which the memoir would be just one of many self-serving political autobiographies.

4 The second volume, which covers a long period from the Lushan Conference in 1959 to Wu's arrest in 1971 and then his life in jail until 1981, may be of interest to both historians and general readers, but for different reasons. To historians it provides valuable historical details that help penetrate the mystery of the Lin Biao incident by 
revealing the inner game of elite politics during the turmoil of the Cultural Revolution, especially during the Ninth Party Congress of 1969 and the 1970 Lushan Conference. For example, the official story insists that Lin Biao wanted to be China's state president, which was part of his plot against Mao Zedong, and that Ye Qun, Lin's wife, once confided this secret intention to Wu Faxian, saying, "What will be Lin Biao's place if China has no state president?" Wu makes it clear in his memoir that Ye Qun never said this to him, and that the source of this statement was Cheng Shiqing, then head of the Revolutionary Committee of Jiangxi Province.

5 The Lin Biao Incident (also known as the September 13 Incident) was one of the most serious political crises the PRC had experienced since 1949. The government had the uncomfortable task of explaining to the Chinese people how it was that their "beloved Vice Chairman" had become a traitor overnight. Naturally, the crime of which he was accused had to be heinous in the extreme, and there could be no compromise in this regard. Wu is a highly relevant witness against the official version of the September 13 Incident, since he was Commander-in-Chief of the Air Force, and the Air Force was key to Lin's alleged coup effort.

Wu makes clear his belief that despite Lin Biao's loyalty, soon after the Ninth Party Congress Mao was already becoming distrustful of Lin and began to manoeuvre against him. Wu records that after the Second Plenum of the Ninth Central Committee at Lushan in the late summer of 1970, it became more and more difficult for Wu and even for Lin to see Mao in person. Mao employed his famous tactic of "casting stones, blending with sand, and digging up the corner" in order to isolate and undermine Lin. Reflecting back on what happened after the Second Plenum, Wu reports, "Even without the September 13 Incident, Mao is determined to get rid of us [Lin and his generals in the Political Bureau] at the Third Plenum of the Ninth Central Committee" (p. 860). Wu also records his disillusionment with Mao: "Mao had always been a glorious image in my heart.... He is the embodiment of truth and justice. I had always been examining my loyalty to him.... Now his image has become bankrupted in my heart. To put it simply, Chairman Mao is not a man whose actions match his words" (p. 859).

7 General readers are less likely than historians to compare Wu's memoir with official versions of the Lin Biao incident. They may be amazed by Mao's spell-binding power and his mastery of the intricacies of political manoeuvring. This is a book about Wu, but Mao's presence is felt on every page. The second volume can be read as a book about the politics of the Mao regime, and about Mao's insatiable hunger for power and his reckless determination to cling to that power at any human cost. It is also about how Maoism entered people's mind and emotions, affecting all their values and relationships.

8 Wu's memoir does not attempt to solve the riddle of the origins of Mao's Terror. It charts the rise and fall of $\mathrm{Wu}$ as a communist functionary, and perhaps unintentionally explains how Maoist tyranny was able to take root in Chinese society and involve millions of ordinary people as silent bystanders and collaborators in its system of terror. The real power of and lasting legacy of the Maoist system can be perceived today in the way Mao's Cultural Revolution is officially remembered in China.

Readers of Wu's memoir may wonder why the Beijing government would rather let the Lin Biao incident remain a mystery instead of setting the record straight. In recent years there have appeared a number of works interested in "reversing the verdict" on Lin Biao, but the incident remains a highly sensitive issue in China. The Beijing regime 
is terrified by the possible "butterfly effect" of historical fact. If the Lin Biao mystery turns out to be something other than what people are expected to believe, many firstgeneration Party leaders and events during the Cultural Revolution will have to be reevaluated. This, in turn, could threaten the regime's political stability, which commands the highest priority.

10 After reading this memoir, one is left with unanswered questions. What general lessons can we draw from what is otherwise a colourful personal story? What does it tell us about a regime that maintains power through fear, lies, and conformity? How did people allow themselves to be led step by step into a helpless situation where basic human decency, honesty, and honour, were suspended or suppressed?

Wu's memoir is a narrative of a failed or unfortunate party functionary, and the author does not come across as particularly likeable. It is only when imprisoned from 1971 to 1981 that Wu expresses political disappointment at Mao's policies, and even then he never suggests that these policies are so misguided and mendacious that they represent nothing less than evil. What preoccupies him is a sense of being personally mistreated and defrauded. He dwells on his own hideous past after the fall of his political fortune. The last decade of his life is dominated by resignation and vexation. He accepts that he is a political scapegoat and victim of Party in-fighting. He puts a premium on his own comfort, convenience, and status, seeing little beyond his own career or perhaps his own family. In these two massive volumes, for example, neither the injustice of the Anti-Rightist Campaign of 1957 nor the suffering brought on by the famine of the early 1960s seems to interest him at all, though he does reveal how Mao turned the tables on Liu Shaoqi, who criticised the hasty policies of the Great Leap Forward at the SevenThousand-People Conference in early 1962 with the help of Lin Biao and others. Wu has a knack for the telling detail, perhaps because he was forced to make numerous confessions during the ten years he was in jail. His moaning is unadorned, one feels, and an authentic perception and expression of what his life was like. He doesn't exaggerate, he doesn't fantasise. This matter-of-fact quality confronting a country run on lies and ideological insanity seems to make him one of the precious honest chroniclers of Mao's China. 